Sveučilište u Rijeci, Filozofski fakultet, 371.12:159.944.4 Republika Hrvatska Pregledni rad

\title{
Jelena Vukobratović
}

Dječji vrtić „Snjeguljica”, Republika Hrvatska

\section{ULOGA PEDAGOGA U PREVENCIJI SINDROMA SAGORIJEVANJA UČITELJA I ODGAJATELJA ${ }^{* *}$}

\begin{abstract}
Apstrakt. U radu se analizira preventivno djelovanje pedagoga u obliku savjetodavnog rada orijentiranog na učitelje i odgajatelje. S obzirom da se profesije učitelja i odgajatelja usmjeravaju na pomaganje i podršku drugim ljudima, te se svrstavaju u takozvane „pomažuće profesije”, profesionalno sagorijevanje na poslu je neizbježna manifestacija sve većih zahtjeva koji se pred njih stavljaju. Istraživanja pokazuju da izloženost sve većim zahtjevima na svim razinama posla kod ,pomažućih profesija“ dovodi do ekstremne količine negativnog stresa, koji dovodi do sindroma sagorijevanja (engl. burn-out), što je predmet interesa istraživača već trideset godina. Ekstremni primjeri sindroma izgaranja mogu prerasti u Karoshi sindrom koji dovodi do smrtnih posljedica. Rad obuhvaća teorijske implikacije ključnih pojmova te raščlanjuje pojavu sindroma sigorijevanja na dvije profesije: učitelje i odgajatelje te preventivnu savjetodavnu ulogu pedagoga kroz suvremenu ulogu tzv. "kritičkog prijatelja"/"refleksivnog praktičara" u "zajednici koja uči".
\end{abstract}

Ključne riječi: profesionalni stres, radna okolina, učitelji, odgojitelji, pedagog.

\section{UVOD}

U posljednje vrijeme svjedoci smo evidentiranja sve brojnijih pojava stresa kod učitelja i odgajatelja, čiji se dugotrajni učinak akumulira u razvijanju tzv. sindroma sagorijevanja (engl. burn-out). U sklopu savjetodavnog rada pedagog ima važnu ulogu u radu s učenicima, roditeljima, učiteljima i odgajateljima. Podaci govore da su posljednje dvije

\footnotetext{
*Sofija Vrcelj, svrcelj@ffri.uniri.hr

** Rad je nastao u okviru kolegija Školski savjetodavni rad pri Odsjeku za pedagogiju, Filozofskog fakulteta u Rijeci.
} 
kategorije ponekad zanemarene ili nedovoljno aktualizirane u radu jer, uz poslove neposrednog rada s učenicima, vođenje evidencije o kulturi ustanove te izradom planova rada pedagozi često ne nalaze dovoljno prostora za rad $\mathrm{s}$ neposrednim odgojno-obrazovnim djelatnicima, što se u ovom slučaju odnosi na učitelje i odgajatelje. Rezultat toga je loša komunikacija na relaciji pedagog - odgojno-obrazovni praktičar te formiranje dvije strane: "teorijske" i "praktične". Praktičari često iskazuju bojazan od ulaska stručnog tima u prostor sobe dnevnog boravka (vrtić) ili u razred (škola), te pedagoge i ostale članove stručnog tima često etiketiraju kao "prijetnju“. Navedeno potvrđuje pronađen iskaz profesorice povijesti koja ističe: «Unatoč dobrim namjerama, čini mi se da upravo u međusobnoj komunikaciji sudionika odgojnoobrazovnog procesa često dolazi do kratkog spoja». ${ }^{1}$ Upravo ovakav dugotrajni stres, koji se odnosi na postojanje problema na relaciji pedagog odgojno-obrazovni praktičar, može se smanjiti ukoliko se prihvati nova uloga pedagoga: pedagoga kao "kritičkog” prijatelja koji praktičaru daje dovoljno autonomije u planiranju i ostvarivanju odgojno-obrazovnih zadaća (škola) odnosno zadataka Nacionalnog kurikuluma za rani i predškolski odgoj i obrazovanje (vrtić). Osim nove uloge "kritičkog prijatelja”, pedagog uzima i ulogu "refleksivnog praktičara", čime smanjuje jaz između stereotipnog viđenja pedagoga kao "suhog" teoretičara.

S obzirom da savjetodavni rad pedagoga traži pozitivnu podršku od strane učitelja i odgajatelja, taj je odnos uzajaman i ponajprije leži u povjerenju kojega gradi kultura pojedine ustanove koja se često u literaturi navodi kao "dobri duh". Humanistička teorija ličnosti ${ }^{2}$ zagovara primjereno uređenje "fizičke" i socijalne okoline, u koju se ubrajaju rad i suradnja s kolektivom, rukovodstvom škole, roditeljima, rad i suradnja prilikom promjene i oblikovanja unutarnje organizacije i sadržaja školskog rada itd.

\footnotetext{
${ }^{1}$ Više informacija na http://gkr.hr/Magazin/Teme/Profesori-ucitelji-odgajatelji-Entuzijazamkao-pokretac-i-smisao, pristupljeno 02.06.2015.

${ }^{2}$ Poznato je da su Rogersove ideje imale utjecaja na shvaćanje obrazovanja i na praksu. Prema Kolić-Vehovec (1998), ističu se središnji principi ove filozofije obrazovanja: želja za učenjem, samousmjeravanje učenja, relevantnost materijala za vlastite potrebe, učenje bez prijetnje i samoevaluacija. Osim toga, Rogers je naglašavao ličnost nastavnika koja treba biti autentična i iskrena, vjerovati u potencijale učenika i iskazivati empatičko razumijevanje. Ovakva ličnost ne može "nastati” u okruženju koje je puno stresogenih čimbenika.
} 
(prema Resman, 2000: 54-55). Provedena su brojna istraživanja (najčešće u svijetu) koja ispituju utjecaj duljine radnog iskustva, spola, položaja i statusa učitelja, demografskih obilježja ispitanika, stupnja obrazovanja. Ipak, ne postoji jedinstven model glavnih determinanti učiteljskog sagorijevanja na poslu, «što sugerira potrebu za daljnjim istraživanjima, osobito s obzirom na različite socijalne kontekste u kojima učitelji rade» (Domović, Martinko i Jurčec 2010, 354). S druge strane, postoji vrlo malo istraživanja koja se odnose na korelaciju sindroma sagorijevanja i odgajateljskog posla, što je alarmantna činjenica jer je odgajateljski posao jednako tako složen i utječe na razvoj pojedinca pozitivno ili negativno (u posljednje vrijeme sve veći broj odgajatelja koji zbog opterećenosti poslom odlaze na sve češća bolovanja). «Pored mnoštva čimbenika koji ga mogu ometati i djelovati vrlo nepoticajno i nepodržavajuće, odgojitelj neminovno može biti izložen stresu» (Tatalović Vorkapić i Lončarić 2013, 422). Navedeno se najčešće dovodi u vezu s činjenicom da je odgajateljski posao na margini društvenog zanimanja te $\mathrm{u}$ praksi i stereotipnom mišljenju javnosti - koja nije upućena u rad odgajatelja - stavljen izvan okvira odgojno-obrazovnog sustava jer ne teži tzv. školifikaciji. «Svakodnevno je iskustvo na poslu pod utjecajem promjena na širim razinama i obratno. Tako, npr. doživljaj stresa na poslu nastavnika i odgojitelja, između ostalog može biti i pod utjecajem društvenih stavova i vrednovanja odgojiteljskog poziva» (Živčić-Bećirević i Ažić 2005, 3). Jedno od prvih istraživanja kod nas proveli su Tatalović Vorkapić i Lončarić 2013. godine, a odnosilo se na traženje odgovora na pitanje: posreduje li profesionalno sagorijevanje učinke osobina ličnosti na zadovoljstvo životom odgojitelja predškolske djece? Tek pokretanjem diplomskog studija Ranog i predškolskog odgoja i obrazovanja ${ }^{3}$ (podizanjem razine studija sa stručne na sveučilišnu) pokrenula su se u nešto većem broju istraživanja koja se tiču ranog i predškolskog odgoja i samim time i odgajatelja koji se promovira kao profesionalac a ne kao "teta čuvalica". Rad Tatalović Vorkapić i Lončarić

\footnotetext{
3 Učiteljski fakultet u Rijeci prvi u Republici Hrvatskoj omogućio nastavak studija odgajateljima djece predškolske dobi te počinje promoviranje potrebe za cjeloživotnim obrazovanjem kao i mogućnost prohodnosti za studente koji upisuju Sveučilišni studij ranog i predškolskog odgoja i obrazovanja na druge (srodne) diplomske studije kao i mogućnost nastavka obrazovanja na poslijediplomskoj razini.
} 
$(2013,448)$ «upućuje na važnost sustavnog istraživanja značajki odgojiteljske profesije koje su usko vezane uz njihovu dobrobit - u ovom konkretnom slučaju složen odnos između osobina ličnosti, zadovoljstva životom i profesionalnog sagorijevanja». Što se tiče spomenutog nedostatka istraživanja sindroma sagorijevanja odgajatelja, isti autori navode: «Uspoređujući stranu i domaću dostupnu literaturu o zadovoljstvu životom stručnjaka koji rade s djecom, vidljivo je da su istraživanja u većoj mjeri provedena na učiteljima/nastavnicima, a tek u manjoj mjeri na odgojiteljima (...). Dosadašnja su se istraživanja na domaćim uzorcima $u$ okviru Eysenckova i Petofaktorskog modela ličnosti usmjerila na usporedbe rezultata na skalama ekstraverzije, ugodnosti, savjesnosti i otvorenosti prema iskustvu kod ispitanih odgojitelja, te neuroticizma i psihoticizma s normama» (Tatalović Vorkapić i Lončarić 2013, 434-435).

\section{ŠTO JE SINDROM SAGORIJEVANJA (ENG. BURN-OUT SINDROM)?}

Istraživanje stresa je multidicslipinaran istraživački problem. Cilj istraživanja koja se bave stresom je ponajprije proširenje spoznaja o ljudskom funkcioniranju u osobnim i profesionalnim ulogama, kao i promjenama kod pojedinaca koje obuhvaćaju: aktivaciju, uzbuđenje, napetost, anksioznost, konflikt, emocionalne promjene, frustraciju i drugo, a pod utjecajem stresa. Interes za istraživanje stresa u Hrvatskoj pojačao se u razdoblju rata i ratom izazvanog stresa (Žužul i Raboteg-Šarić, 1992). Vrlo brzo su se pojavila i istraživanja koja se bave profesionalnim stresom pomagača (Ljubotina i Družić, 1996; Ajduković, Ajduković i Ljubotina, 1997). Sindrom sagorijevanja na poslu kao oblik profesionalnog stresa i dalje je nastavio pobuđivati interes istraživača (Škrinjar, 1996; Jenić, 2002) s obzirom da se zna da stres djeluje nepovoljno na zdravlje ljudi i izaziva mnogobrojne ekonomske gubitke povezane sa izostancima s posla i smanjenjem radne efikasnosti.

Prije svega je potrebno raščlaniti pojmove: stres i sindrom sagorijevanja. «Stres se najčešće definira kao sklop negativnih emocionalnih, tjelesnih i/ili ponašajnih reakcija do kojih dolazi onda kada osoba neku situaciju ili događaj procijeni opasnom ili uznemiravajućom, uslijed čega je 
nesklad između osobe i okoline vrlo izražen» (Lazarus, 1975, prema Tatalović Vorkapić i Lončarić 2013, 436). «U ispitivanju se stresa prosvjetnih radnika istraživači usmjeravaju na ispitivanje sagorijevanja na poslu kao stanja emocionalne i fizičke iscrpljenosti nastavnika koji su neuspješni u efikasnom suočavanju s dugotrajnim stresom» (Živčić-Bećirević i Ažić, 2005, 4). Stres je povezan i sa stresorima koji proizlaze iz osobina radne okoline, organizacije rada i načina komuniciranja u organizaciji, kao i mnogim drugim svakodnevnim specifičnim čimbenicima koje je teško kvalificirati u određene kategorije jer su previše ovisni o čitavom sklopu odnosa u ukupnoj socijalnoj situaciji u kojoj se događaju. Sve to može s vremenom dovesti do razornih posljedica kako po samog stručnjaka tako i na kvalitetu i razinu stručnog rada.

Tijekom sedamdesetih godina prošlog stoljeća sindrom sagorijevanja zaokuplja sve veću pozornost kliničkih psihologa. Freudenberger (1974) je među prvima definirao taj sindrom kao «sagorijevanje energije pod utjecajem permanentnog stresa u području profesionalnog života, odnosno osjećaj neuspjeha i istrošenosti» (Domović, Martinko i Jurčec 2010, 351). Prema Škrinjar (1974), «to je stanje iscrpljenosti u kojem pojedinac ne može učinkovito funkcionirati». Maslach (1982) sagorijevanje na poslu definira kao «sindrom emocionalne iscrpljenosti, depersonalizacije i smanjenog osobnog i profesionalnog ispunjenja djelatnika koji rade $\mathrm{s}$ ljudima. Emocionalna iscrpljenost se odnosi na osjećaj emocionalne "rastegnutosti" i iscrpljenosti zbog rada $\mathrm{s}$ ljudima. Depersonalizacija podrazumijeva bezosjećajan i ravnodušan odnos prema klijentima, a smanjeno osobno postignuće se odnosi na opadanje osjećaja kompetencije i uspjeha u radu s ljudima» (Domović i sur. 2010, 352). Sindrom sagorijevanja na poslu jedna je od najnepovoljnijih posjedica dugotrajne izloženosti profesionalnom stresu (Ajduković i Ajduković 1996). Sindrom sagorijevanja ispituje se Maschlachinim upitnikom sagorijevanja (Maslach Burnout Inventory) a «temelji se na modelu koji polazi od toga da su posljedice duge izloženosti stresu na poslu emocionalna iscrpljenost, depersonalizacija drugih i značajno snižena percepcija osobnog postignuća, koje se onda posebno i mjere » (Tatalović Vorkapić i Lončarić 2013, 436). Istraživanja autora Brand i Holsboer-Trachsler (2010) pokazuju da sindrom sagorijevanja podjednako 
pogađa muškarce $\mathrm{i}$ žene, a prevalencija rangira od $10 \%$ do $50 \%$, ovisno o profesiji, mjerama ispitivanja i populaciji. Domović i sur. (2010, 351-352) ističu: «Sagorijevanje je naglašeno u zanimanjima koja su vezana uz rad s ljudima, a za posljedicu ima razvoj negativnih, dehumaniziranih stavova prema sebi, obitelji, poslu i životu općenito (...). Prvi znak sagorijevanja na poslu je kroničan umor, a slijede ga različite emocionalne promjene». Nerijetko sindrom sagorijevanja preraste u tzv. Karoshi sindrom, koji često ima smrtonosne posljedice - najčešće kardijalni infarkt. Koić i Poredoš Lavor (2009) ističu da se upravo po tome razlikuje sindrom sagorijevanja od Karoshi sindroma (potonji ima fatalne posljedice). S obzirom na opterećenje poslom, učitelji i odgajatelji nerijetko rade prekovremeno (izvan ustanove pripremajući materijale za rad), čime nastaje povišeni negativni stres ukoliko se posao ne stigne obaviti. Povišeni stres se nerijetko pretvara $u$ sindrom sagorijevanja ako poprilično dugo traje a njegove posljedice $u$ Karoshi sindrom.

\section{ODGAJATELJ/UČITELJI I POJAVA SINDROMA PROFESIONALNOG SAGORIJEVANJA}

Učiteljsko i odgajateljsko zvanje (profesija) pripada skupini tzv. "pomažućih profesija”. Navedeno potvrđuje Čudina Obradović (1993): «Učiteljska profesija pripada u "pomažuće” profesije kojima je glavna sastavnica rad s učenicima i briga za njihovu dobrobit». Ajduković i Ajduković (1994) dodaju: «Pojedinci koji svoj profesionalni rad usmjeravaju na pomaganje i podršku drugim ljudima, pripadaju u skupinu "pomagača” ili "pomažućih profesija” koje su stresogene zbog neposredne komunikacije i uživljavanja u emocionalna stanja i patnje drugih osoba». Frey Škrinjar i Župan Galić $(2012,19)$ dodaju: «Činjenica je da se u edukaciji za zanimanja pomagača ne posvećuje gotovo ništa ili vrlo malo pažnje sindromu profesionalne iscrpljenosti, odnosno mogućim načinima njegove prevencije i strategijama suočavanja sa stresom». Prema Škrinjar (1996), pomagači koji se odlučuju za ta zanimanja su često entuzijasti, perfekcionisti i osobe koje idealiziraju svoje zanimanje i imaju visoka očekivanja te su česti kandidati za sagorijevanje. Postavlja se pitanje utječe li duljina radnog iskustva, položaja $i$ 
statusa na pojavu sindroma sagorijevanja na poslu? Prema Chanu (2003), proces sagorijevanja može započeti u fazi inicijalnog obrazovanja i uvođenja pripravnika u rad. «Rezultati istraživanja koje je proveo Chan pokazuju da postoji značajna korelacija između učinkovitosti učitelja i faktora sagorijevanja. Kako se povećava razina učinkovitosti i kompetencija, smanjuje se stupanj sagorijevanja».

Navedeno implicira zaključak da pojedinac koji se osjeća uspješno u učiteljskoj i odgajateljskoj profesiji može izbjeći pojavu sindroma sagorijevanja na poslu. Stoga bi preventivna uloga pedagoga $\mathrm{u}$ školskom/vrtićkom okruženju bila razvijati kompetencije učitelja i odgajatelja. Prema Mušanović (2007), «multidimenzionalni karakter učiteljskog zvanja obuhvaća mnoštvo različitih zadataka koji nisu samo instrumentalne (kognitivne, metodološke, lingvističke i tehnološke vještine) $i$ sistemske (planiranje, poduzetništvo, vodstvo, kreativnost i prilagodljivost) kompetencije, već se svakodnevno isprepliću i prožimaju s individualnim kompetencijama».

\section{Učitelji}

U istraživanju koje se tiče čimbenika učiteljskog sagorijevanja na poslu a koje su kod nas proveli Domović, Martinko, Jurčec (2010), ispitivane su razlike u profesionalnom sagorijevanju 229 učitelja/ica (107 učitelja/ica razredne nastave i 121 učitelj/ica predmetne nastave) iz 19 osnovnih škola s područja 17 hrvatskih županija. Ispitivale su se razlike s obzirom na spol, godine, radno iskustvo, razrednu ili predmetnu organizaciju nastave, tip naselja u kojemu rade, povezanost dimenzija profesionalnog sagorijevanja sa samopoštovanjem i određenim demografskim varijablama. Sagorijevanje na poslu je pri tome promatrano kroz tri dimenzije - emocionalnu iscrpljenost, depersonalizaciju i osobno postignuće. Istraživanje je pokazalo da učitelji osjećaju višu razinu depersonalizacije naspram učiteljica. Autorice istraživanja ističu kako se spol pokazao kao značajan prediktor u pojavi depersonalizacije te kao mogući razlog navedenom ističu opadanje društvenog ugleda učiteljske profesije koja je poprilično feminizirana. Isto tako, istraživanje je pokazalo da učitelji/ce $\mathrm{s}$ najduljim radnim stažom 
doživljavaju višu razinu emocionalne iscrpljenosti nego što je to slučaj s mlađim kolegama/icama. «Učitelji su zbog prirode svoje profesije, koja se manifestira kroz rastući broj zahtjeva koji se pred njih postavljaju (...) izloženi većoj količini stresa koja može dovesti do sindroma sagorijevanja. To upućuje na potrebu istraživanja sindroma sagorijevanja na poslu $\mathrm{u}$ učiteljskoj profesiji» (Domović, Martinko, Jurčec 2010, 355).

\section{Odgajatelji}

Proučavajući dostupnu literaturu koja je mahom usmjerena na proučavanje nastavničkog stresa, koji je značajno viši od stresa u zanimanjima koja ne uključuju rad s djecom (DeNobile i McCormick, 2005; Gonçalves i Neves, 2012; Oi-Ling, 1995; Ritvanen, Louhevaara, Helin, Vaisanen i Hanninen, 2006 prema Tatalović Vorkapić i Lončarić 2013), ne manje važno je usmjeriti se na stres odgajatelja. U prilog navedenome, autori Živčić-Bećirević i Smojver-Ažić (2005) ističu i nalaze koji su utvrđeni primjenom metode dnevnika i analize sadržaja na temelju iskaza nekoliko odgajatelja koji svjedoče da naročito stresnim vide slijedeće čimbenike: vremenski pritisak, zadovoljenje potreba djece, suočavanje s poslovima izvan svoje profesionalne domene, zadovoljenje osobnih potreba, interakcija s roditeljima djece u vrtiću, interpersonalni odnosi i stalne prilagodbe promjenama predškolskog kurikuluma.

Tatalović Vorkapić i Lončarić (2013) proveli su jedno od prvih istraživanja na našem području o pojavi sindroma sagorijevanja kod odgajatelja. Ispitano je 295 odgajatelja (od toga 4 muškog spola) iz cijele Republike Hrvatske, prosječne dobi 37 godina. Glavno pitanje istraživanja glasilo je: posreduje li profesionalno sagorijevanje učinke osobina ličnosti na zadovoljstvo životom odgojitelja predškolske djece? «Osnovni je cilj ovog istraživanja bio utvrditi posreduje li profesionalno sagorijevanje efekte osobina ličnosti na zadovoljstvo životom te imaju li osobine ličnosti izravne efekte na zadovoljstvo životom, neovisne o stupnju profesionalnog sagorijevanja» (Tatalović Vorkapić i Lončarić 2013, 438). Rezultati istraživanja pokazuju slijedeće: «Rezultati su pokazali značajne izravne efekte ekstraverzije i neuroticizma na zadovoljstvo životom odgojitelja, što je 
potvrdilo nalaze dosadašnjih istraživanja. Osim izravnih efekata ekstraverzija ima posredan pozitivan efekt na zadovoljstvo životom posredovan smanjenjem emocionalne iscrpljenosti, a neuroticizam ima posredan negativan efekt na zadovoljstvo životom» (Tatalović Vorkapić i Lončarić 2013, 431). Osim ovog istraživanja, poznato je i nešto ranije provodeno istraživanje Živčić-Bećirević i Ažić (2005) Izvori stresa na poslu odgojitelja $u$ dječjim vrtićima. «Utvrđeno je da odgojitelji sa srednjom duljinom staža (19-27 godina) percipiraju međuljudske odnose stresnijima od kolegica $\mathrm{s}$ manje staža (10-18 godina), dok odgojitelji s najviše godina staža (iznad 28 godina) procjenjuju radne uvjete stresnijima od onih s manje staža» (2005, $3)$.

U ustanovama ranog i predškolskog odgoja i obrazovanja nerijetko postoji tzv. šefovski sustav (ravnatelj, stručni suradnik - pedagog, psiholog) upravljanja pri čemu stručni tim čini "jednu stranu“ a odgajatelji "drugu stranu". Često su te dvije strane u konfliktu. Rigidan odnos među djelatnicima postaje stresogen čimbenik i potencijalni okidač za razvoj profesionalnog sindroma sagorijevanja. Naime, takav način upravljanja smatra se tradicionalnim, a zajednica je strogo hijerarhijski organizirana na način da šef ima pravo i obvezu upravljati ljudima i stvarima. Navedeno potvrđuje autorica Ljubetić $(2009,32)$ : «Pojedinci koje se stalno nadzire ne mogu razviti učinkovit sustav samoregulacije i samopoštovanje, ni doživjeti samoostvarenje, a to su vrijednosti, odnosno osobine koje bi odgojnoobrazovni sustav trebao razvijati i poticati, kako kod djece tako i kod odraslih». Ista autorica navodi Bensonov stav da «prerigidan rukovoditeljski sustav koči fleksibilnost, ignorira individualne potrebe i pojedinčeve kapacitete da sudjeluje... to paralizira misli i djelovanje... Organizacije koje upravljaju na kompetitivne i kontrolirajuće načine gube svoj ljudski potencijal» (Benson, 2006, prema: Ljubetić, 2009, 33). Transakcijski model vođenja treba zamijeniti transformacijski model. «Temeljna postavka ovog koncepta je distribucija moći među svim čimbenicima odgojno-obrazovnog procesa» (Ljubetić, 2009, 34). Upravo distribuirano vođenje ustanove smanjuje mogućnost stresogenih čimbenika jer se svaki pojedinac unutar nje osjeća važnim i kompetentnim što umanjuje osjećaj frustriranosti, nezadovoljstva i sl. 


\section{NOVA ULOGA PEDAGOGA: PEDAGOG KAO “KRITIČKI PRIJATELJ“ I "REFLEKSIVNI PRAKTIČAR" U ORGANIZACIJI KOJA UČI}

Termini kao što su "kritički prijatelj”, "refleksivni praktičar" te "organizacija koja uči” u literaturi se kod nas evidentiraju nešto kasnije nego što je to slučaj u svijetu (otprilike dvadesetak godina duže nego kod nas). Nova uloga pedagoga podrazumijeva vođenje kolektiva u ulozi "kritičkog prijatelja..4. Pojam "kritički prijatelj" među prvima koristi Lawrence Stenhouse. Za njega je kritički prijatelj osoba koja daje savjete i surađuje s učiteljem u akcijskom istraživanju. Za razliku od savjetnika, "kritički prijatelj” je prije svega učiteljev prijatelj koji je više zainteresiran za njegovo napredovanje nego za napredovanje istraživanja. Kroz suradnju, on nastoji pomoći učitelju da razvije svoje refleksivne kapacitete i učenje (Kember i sur, 1999, str. 464). ${ }^{5}$ Kritički prijatelj treba biti spreman upustiti se u opisani problem (npr. situaciju na nastavi, određeni način postupanja nastavnika i sl). «Savjetodavni djelatnici moraju živjeti sa školom, a u radu polaziti od njezinih potreba i potreba pojedinih subjekata. Tako orijentirane savjetodavne službe ne zatvaraju se u svoje urede, već se aktivno uključuju u zajednički život u školi» (Resman, 2000, 55). Kritički prijatelj pušta da mu sugovornik opiše konkretnu situaciju, planiranu namjeru ili doživljeno iskustvo i pokušava se uživjeti $u$ tu situaciju. On najprije postavlja informativna pitanja kako bi što bolje razumio i ako je potrebno moli svog sugovornika da pri opisivanju iskustava iz nastave ostane na razini opisa situacije tj. da ako je moguće ne vrednuje. Takvo bi vrednovanje kritičkom prijatelju onemogućilo stjecanje ispravne predodžbe o situaciji. Kritički prijatelj ne izražava kritike i ne iznosi ishitrene prijedloge za rješenje problema kako svog sugovornika ne bi gurnuo u određenom smjeru. On unosi svoja vlastita iskustva tamo gdje je važno predvidjeti posljedice ideja ili prijedloga. Kritički prijatelj sa svojim sugovornikom gradi takozvani krug akcije i refleksije tj. daje potporu pri planiranju određene namjere,

4 Za više informacija pogledati https://dnevnikuciteljice.wordpress.com/2011/.../kritickiprijatelj-tko-je-to, pristupljeno 05. 06. 2015.

5 Za više informacija pogledati http://mzu.sbnet.hr/clanak2200-0-1284.htm, pristupljeno 05. 06. 2015. 
promatra svoju kolegicu ili svojeg kolegu - ako je moguće - pri provedbi tog plana i nudi razgovore nakon provedbe u kojima se $\mathrm{s}$ određenih stajališta reflektira o ostvarenom procesu (prema Delić, 2011). Ponajprije svaki pedagog treba jačati strategije angažmana pojedinca, omogućavati afirmaciju i uspješno zadovoljavanje potreba i uživanje prava pojedinca, omogućavati usmjerenost na stalni rast i kvalitetu te izgradnju zajedničke vizije u svrhu izgradnje "zajednice koja uči”. Pojam "refleksivni praktičar" u teoriji i praksi ranog i predškolskog odgoja i obrazovanja u Republici Hrvatskoj uvodi profesorica Mirjana Šagud 2006. godine svojom knjigom Odgajatelj kao refleksivni praktičar. Uskoro se taj pojam prenosi i na stručne suradnike za koje je praksa evidentirala nužnost teorijske refleksije u praktične uvjete. Upravo činjenica da i pedagog i ostali članovi stručnog tima prema novoj paradigmi postaju izjednačeni s praktičarima može doprinijeti osjećaju jednakopravnosti kod jednih i drugih. Formiranje refleksivne prakse postaje novi konceptualni i metodološki pristup praksi. Postavlja se pitanje: što je/tko je refleksivni praktičar? «Refleksivni praktičar stvara, odnosno gradi refleksivnu praksu na osnovi svog razmišljanja o njoj - prije i poslije aktivnosti i djelovanja te tijekom akcije što je karakteristika vrsnog (refleksivnog) praktičara» (Šagud, 2006, 14). Pedagog kao “refleksivni praktičar" treba jednako kao i praktičar (učitelj ili odgajatelj) razvijati meta kognitivno viđenje tzv. teorije o akciji i teorije u akciji kako bi izbjegao nesklad onoga što misli da radi i što realizira u praksi. Refleksivna praksa u djelovanju (u praksi) znači provođenje akcijskih istraživanja i vršenje samoevaluacije svog rada. Akcijska istraživanja trebaju i mogu provoditi učitelji/odgajatelji ali i pedagozi. «U akcijskom istraživanju važnu ulogu imaju kritički prijatelji. Kritički prijatelj je osoba od povjerenja koja postavlja provokativna pitanja, pronalazi podatke koji se zatim ispituju na razne načine i nudi kritiku rada kao prijatelj» (Costa i Kallick, str. 50). Već tijekom studija budući pedagozi mogu i trebaju se osposobljavati za važnu profesionalnu ulogu kritičkog prijatelja jer ona zahtijeva mnogo znanja, iskustva i neprekidnog usavršavanja. Stručni suradnik pedagog ima sve predispozicije da bude kvalitetan kritički prijatelj: stručno pedagoško obrazovanje, iskustvo suradnje u nastavnim procesima, otvorenost i spremnost na suradnju, znanje da daje savjete kojima utječe na djelovanje nastavnika u konkretnim 
situacijama. Osim toga, kao kritički prijatelj ima mogućnost čestih posjeta nastavi/odgojnoj grupi kako bi sustavno prikupljao podatke, snimao nastavni/odgojnoobrazovni proces tako da omogući što jasniji opis onoga što se događalo, a nakon toga može biti od velike pomoći nastavniku u evaluaciji planiranih aktivnosti. Akcijska istraživanja pružaju novu mogućnost suradnje učitelja/odgajatelja i stručnih suradnika pedagoga koji mogu biti inicijatori istraživanja, suistraživači i/ili kritički prijatelji tijekom istraživanja.

Kao što je ranije navedeno, pedagog treba napustiti staru racionalnu paradigmu u čijem temelju leži transakcijski pristup te "ući u razred/grupu”. Tek kada uspostavi dijalog sa učiteljem/odgajateljem kao "kritički prijatelj”, koji je ujedno i "refleksivni praktičar" (sam sebe preispituje o svom načinu djelovanja a ne samo druge), moći će se govoriti o pravoj "zajednici koja uči”. U domeni samoevaluacije "refleksivni praktičar” pedagog, učitelj i odgajatelj nužno istražuje svoju praksu izgrađujući postupke kojima provjerava teorijske hipoteze, potvrđuje ih ili odbacuje te postavlja nove.

Pedagog kao "kritički prijatelj” i "refleksivni praktičar" u svrhu preventivnog savjetodavnog rada s učiteljima/odgajateljima treba razvijati $i$ svoju praktičnu kompetenciju. Teorijsko znanje naime nije dovoljno za ostvarenje te vrste kompetencije jer kao što znamo "znanja” nisu rascjepkani niz informacija već se od današnjeg čovjeka traži da postane takozvani "renesansni čovjek" - čovjek koji ima cjelokupnu viziju i spoznaju onoga što radi, kojemu "znanje” nije svrha samo po sebi već želja za cjelovitim razvojem. Praktična kompetencija pedagoga može se steći samo - praktičnim djelovanjem. Razvijajući praktičnu kompetenciju pedagog razvija svoju implicitnu pedagogiju - svoju vlastitu filozofiju o profesiji. Reakcije kolektiva na akcije pedagoga u školi/vrtiću mjerilo su za razumijevanje kakva je njegova implicitna pedagogija kao vrijednosna orijentacija.

\section{NAČINI I OBLICI RADA PEDAGOGA U PREVENCIJI SINDROMA PROFESIONANOG SAGORIJEVANJA UČITELJA I ODGAJATELJA}

Pedagog jasno preuzima sasvim novu ulogu $\mathrm{u}$ humanističko orijentiranoj paradigmi te iz tog razloga treba djelovati u smjeru razvijanja kompetencija učitelja i odgajatelja, razvijati njihovu autonomiju, poticati na 
stručno usavršavanje i u konačnici na cjeloživotno obrazovanje, održavati radionice i druge oblike savjetovanja, davati podršku osobama koje su na početku radnog vijeka, razvijati komunikacijske vještine učitelja/odgajatelja, njegovati kulturu ustanove stvarajući duh "zajednice koja uči” te ukoliko postoji potreba koristiti preventivne koncepte kao što je coping ${ }^{6}$. Velik dio navedenih zadataka odnosi se i na rad psihologa, međutim mnoge škole i vrtići nemaju kompletan razvojno-stručni tim te je stoga tijekom školovanja pedagoga nužno pojedincima obratiti pozornost upravo na ove segmente djelovanja koji su često potrebiti u praksi. Budući da suvremena pedagoška djelatnost u svojoj osnovi ima ideju o zajednici koja uči, u skladu s time osmišljavaju se područja u kojima pedagog djeluje i unapređuje ih. Prema Koncepciji razvojno pedagoške djelatnosti stručnih suradnika (Jurić i sur, 2001), ta su područja sljedeća: priprema za ostvarenje programa odgojnoobrazovne ustanove, neposredno sudjelovanje u odgojno-obrazovnom procesu, praćenje i vrednovanje odgojno-obrazovnog procesa, njegovih sudionika i ostvarenih rezultata, osposobljavanje i stručno usavršavanje odgojno-obrazovnih djelatnika te informacijska i dokumentacijska djelatnost. Sukladno tome, suvremeni pedagog ima jednu od važnijih uloga u odgojnoobrazovnom procesu. Unatoč napretku u pedagoškim istraživanjima, odgojno-obrazovne ustanove mogle bi izgubiti svoje prednosti ako se ne suoče s jazom između naprednih teorija i prakse odgojno-obrazovnih institucija koja zaostaje. U preventivnom savjetodavnom radu pedagoga $\mathrm{s}$ učiteljima i odgajateljima nužno je posvetiti dovoljno pozornosti u razvijanju kompetencija odgojno-obrazovnih djelatnika (učitelja, odgajatelja ali i stručnog tima). Posljedice stresa u radu nerijetko se očituju u somatskom i psihološkom aspektu čovjekovog djelovanja. Emocionalna iscrpljenost, depersonalizacija i smanjeno osobno postignuće rezultat su raznih stresora čiji se dugotrajni učinak akumulira u sindrom profesionalnog sagorijevanja, sindrom koji se manifestira kroz razdražljivu, netolerantnu i nestrpljivu osobu. Koliko su važni upravo organizacijski uvjeti (u ovom slučaju u

\footnotetext{
${ }^{6}$ Pristup koji se često koristi u strategijama svladavanja profesionalnog sagorijevanja edukacijskih rehabilitatora kao učitelja djece s poremećajima autističnog spektra. Naime, određena istraživanja su pokazala da su "specijalni”" učitelji skloniji sindromu profesionalnog sagorijevanja od onih koji su u procesu inkluzije.
} 
školama) ističe Dorman (2003) nabrajajući moguće organizacijske stresore: nedostatak vrednovanja učitelja, uskraćivanje pravovremenih i potrebnih informacija, povećanu birokratizaciju kao i smanjenu autonomiju učitelja (prem Maleš i sur. 2010).

S obzirom da je pedagog taj za kojega se smatra da je glavni organizator izrade programa $\mathrm{i}$ organizacije provođenja istog treba uzeti $\mathrm{u}$ obzir njegovanje kulture ustanove u kojoj će se svaka osoba koja u njoj “živi“ osjećati ugodno i razvijati svoje potencijale. Suprotno od takozvanog transakcijskog načina vođenja za koji je karakterističan stereotipan opis posla pedagoga, «pedagozi u radu s učiteljima provjeravaju realizaciju rada učitelja (nazočnost na nastavi, realizaciju planova i programa i sl). Pedagozi analiziraju rezultate škole na područjima uspjeha, vladanja, popravnih ispita $i$ sl. Organiziraju istraživački rad u školama i stručno usavršavanje učitelja...» (Resman, 2000, 46).

Sve navedeno nije moguće ukoliko sam pojedinac ne osjeti sigurnost u pedagogu škole/ vrtića. Zato je važno raditi na unaprjeđivanju komunikacije (verbalne $i$ neverbalne). «Kakve veze ima komunikacija s pomagačkim stresom, odnosno sagorijevanjem na poslu? (...) Povlačenje u sebe i izbjegavanje komunikacije s kolegama jedan je od znakova uznapredovalog sagorijevanja. $\mathrm{S}$ druge strane, rijetko i nekvalitetno komuniciranje među kolegama je jedan od značajnijih izvora profesionalnog stresa» (Ajduković, Ajduković, 1996, 63). Poticajnu komunikaciju odlikuje odgovornost za rad i uspjeh, poticanje na promjene, inovacije, samostalnost, slobodu izražavanja, samovrednovanje i radovanje uspjesima drugih. «Vjerojatno ni u jednom području ljudskog djelovanja visoka kvaliteta komunikacije nije toliko važna kao u prosvjetnoj djelatnosti» (Ljubetić, 2009, 44). U svrhu razvijanja komunikacijskih kompetencija i izbjegavanja poruka jezika neprihvaćanja u kolektivu vrlo je važno razvijanje socijalnih vještina kod učitelja/odgajatelja kroz razne oblike radionica i seminara za učenje komunikacijskih vještina.

Vrlo je važan rad pedagoga s osobama koje su na početku radnog vijeka, kada većina mladih prolazi kroz krizno razdoblje koje karakterizira visoka razina stresa, frustracije, nervoze i umor. Nerijetko se događa da upravo u tom stadiju neki napuštaju odabranu učiteljsku ili pak odgajateljsku 
profesiju. Odraz je to i društva u kojemu živimo koje nerijetko osuđuje, proklamira određene vrijednosti a poprilično postaje inertno za bilo kakvu promjenu. «Činjenica je da se barem u našoj praksi, mlađi neiskusni ali "svježi rehabilitatori, učitelji upućuju u rad s "težim” skupinama (razredima) a da pri tome nemaju mentora tj. primjerenu profesionalnu podršku u svom uvođenju u posao nego se jednostavno računa na njihov entuzijazam, “neistrošenost”...» (Frey Škrinjar, Župan Galić, 2012, 19-20). Položaj učitelja i odgajatelja na društvenoj ljestvici u Republici Hrvatskoj je na poprilično lošem mjestu ukoliko usporedimo rezultate sa rezultatima primjerice nordijskih zemalja. Ipak, nordijske zemlje mogu biti primjer ali ne i model koji se uzima kao savršeni primjer jer je ipak nacionalni identitet sam po sebi poseban te se kao takav treba uzimati i razvijati sa svim mogućim sredstvima i alatima (ponajprije ljudskim potencijalima). Pedagog ima ključnu ulogu u gradnji kulture proaktivne ustanove - ustanove koja će djelovati “iznutra prema van", ustanove koja je "zdrava” iznutra sa svim svojim sastavnicama (učenicima, učiteljima i drugim osobljem) te koja ima zajedničku misiju koju produciraju svi a ne samo pojedinci na vrhu takozvane hijerarhijske ljestvice škole/vrtića.

Jedan od zanimljivih preventivnih pristupa je koncept svladavanja stresa koji se u literaturi označava terminom COPING. Sinonimi su: svladavanje stresa, prevladavanje stresa, svladavanje straha, suočavanje sa situacijom i sl. Prema Frey Škrinjar i Župan Galić $(2012,14)$, «pojam potječe od Lazarusa (1966) koji ga definira kao nastojanje da se svladavaju stanja boli, opasnosti, prijetnje, izazova, kada rutinska ili automatska reakcija nije prisutna. (...) Cilj pokušaja svladavanja je otklanjanje doživljenog osjećaja neravnoteže između zahtjeva i vlastitih sposobnosti». Jackson i sur. (1986) ističu da proces sadrži bihevioralne i kognitivne ("intrapsihološke“) reakcije individue i uključuje mehanizme obrane "defense" (prema Frey Škrinjar i Župan Galić, 2012, 14). Postoje dvije coping strategije: coping s orijentacijom na problem (pokušaj odmicanja od stresora, prevencija budućeg stresa), i coping s orijentacijom na emocije (relaksacija). Pedagog može kombinirati ove dvije kategorije ili pak koristiti jednu ukoliko se pokaže najveća potreba za njom. Ova strategija pridonosi osjećaju zajedništva, posebno druga emocionalna kategorija. Pedagog bi u svojoj službi trebao 
uočiti važnost preventivnog djelovanja pri uočavanju elemenata stresa kod pojedinih učitelja/odgajatelja. «Pravovremeno uočavanje sindroma sagorijevanja omogućit će organiziranje podrške i pomoći učiteljima kako bi se ono smanjilo, a vratila se veća efikasnost i povećale kompetencije učitelja» (Domović, Martinko, Jurčec 2010). U literaturi se najčešće navode slijedeći stresori: nemogućnost dovoljne educiranosti o pojedinim problemima unutar odgojno-obrazovne prakse, loša organizacija rada ustanove, poslovi koji ne spadaju u opis radnog mjesta, izloženost verbalnoj agresiji učenika/roditelja, nemogućnost izražavanja vlastite kreativnosti, česta izloženost kritikama, česte promjene zakonskih regulativa, izostanak podrške kolega i stručnog tima, loš odnos s kolegama u zajednici, osjećaj prevelike odgovornosti, preopterećenost poslom u smislu rokova, velikog broja djece i sl.

Osim navedenog, u funkciji tzv. ,zajednice koja uči učitelji/odgajatelji bi trebali imati dovoljno autonomije $\mathrm{u}$ pripremi/organiziranju odgojno-obrazovnog rada u kojemu će se očitovati njihove kompetencije te mogućnost napretka i smanjiti osjećaj frustriranosti koju nerijetko čini hijerarhijska ljestvica države/škole/vrtića. Prema riječima Jovanke Pap - učiteljice povijesti, «učitelji se još uvijek moraju držati postojećih planova i nemaju takvu slobodu intervencije u sadržaje, bez obzira na usmjerenost na kompetencije učenika. Često se zato stječe krivi dojam da su učitelji kočnica promjena (...) problem nisu učitelji nego nedovršenost reformi koja često vodi formalnoj primjeni u praksi». ${ }^{7}$ Navedeni iskaz se trenutno može povezati s aktualnom cjelovitom obrazovnom reformom čiji će se rezultati vidjeti tek za devet do četrnaest godina. Nacionalni problem donošenja, povlačenja i izmjena reformi posebno se reflektira na odgojnoobrazovni sustav koji je nerijetko žrtva aktualne vlasti. Odgojno-obrazovni sustav ne bi trebao biti meko tkivo za takve brze političke izmjene i dopune jer se time povećava razina stresa kod odgojno-obrazovnih djelatnika, što rezultira manjom motivacijom za rad koja se očituje u radu ,na terenu, s učenicima/djecom.

Pedagog treba stvarati okruženje koje je pozitivno/afirmirajuće ali i realno orijentirano na potrebe zajednice. Okruženje koje producira uzajamnu

\footnotetext{
${ }^{7}$ Više informacija na http://gkr.hr/Magazin/Teme/Profesori-ucitelji-odgajatelji-Entuzijazamkao-pokretac-i-smisao , pristupljeno 02.06.2015.
} 
podršku uz kvalitetnu komunikaciju može doprinijeti uklanjanju stresogenih čimbenika na poslu. «Kvaliteta rada odgojitelja izravno je povezana s onim kako se on osjeća na poslu. Ako se osjeća dobro i pozitivno, vidi smislenost svojeg rada s djecom i raduje se istraživanju, učenju i suradnji, sve te osobine prenijet će na djecu» (Tatalović Vorkapić i Lončarić 2013, 422). Pedagog u vrtiću treba raditi s odgajateljima na razvoju komunikacijskih vještina putem radionica i individualnog savjetovanja. «Specifičnosti odgojiteljskog posla proizlaze iz činjenice da su svakodnevno izloženi višestrukim interakcijama i odnosima, i to s djecom različite razvojne razine, kao i odraslima (roditelji, kolege, nadređeni)» (Živčić- Bećirević, Ažić, 2005, 5). O kompleksnosti i odgovornosti pedagoške uloge Maleš i sur. (2010) kazuju da je «odgovarajuće osposobljen pedagog onaj koji je svjestan konteksta i potreba zajednice u kojoj djeluje». Pedagog kao stručnjak surađuje sa svim drugim sudionicima odgojno-obrazovne djelatnosti/procesa u školi. Prati, istražuje i analizira nastavni rad te predlaže načine i sadržaje za unapređivanje i poboljšavanje nastave i cjelovitoga odgojno-obrazovnog rada u školi. Zadaće su stručnih suradnika (pa tako i pedagoga): rad na stvaranju optimalnih uvjeta za cjeloviti razvoj osobnosti djece i učitelja, rješavanje razvojnih problema djece, stvaranje poticajnih odgojnih sredina za uspješno učenje u školskim i izvanškolskim uvjetima, profesionalni rad i razvoj karijere stručnih djelatnika ustanove, obrazovanje roditelja za odgovorno roditeljstvo, unapređivanje kvalitete programskih, organizacijskih i materijalno-tehničkih uvjeta rada i unapređivanje školskog i odgojno-obrazovnog sustava (Jurić i sur, 2001).

\section{ZAKLJUČAK}

Autorice rada ukazuju na značaj istraživanja na području preventivne savjetodavne uloge pedagoga $s$ učiteljima i odgajateljima ranog i predškolskog odgoja i obrazovanja uzimajući u obzir zapostavljenost odgajateljske profesije u recentnim istraživanjima. Kroz rad su se uvažavali empirijski dokazi te su uzeti kao baza za teorijsko istraživanje. Budućnost posla pedagoškog profila, u smislu unaprijeđivanja kvalitete i njegovoga razvoja u profesionalnom smislu, ovisi isključivo o angažiranosti ljudi iz ovoga područja. Pedagog jasno preuzima sasvim novu ulogu u humanističko 
orijentiranoj paradigmi, te iz tog razloga treba djelovati u smjeru razvijanja kompetencija učitelja i odgajatelja, razvijati njihovu autonomiju, poticati na stručno usavršavanje i u konačnici na cjeloživotno obrazovanje, održavati radionice i druge oblike savjetovanja, davati podršku osobama koje su na početku radnog vijeka, razvijati komunikacijske vještine učitelja/odgajatelja, njegovati kulturu ustanove njegujući duh "zajednice koja uči”.

Suvremene odrednice odgoja i obrazovanja traže promjenu uloge pedagoga: iz tradicionalne uloge do uloge refleksivnog praktičara koji djeluje u takozvanoj zajednici koja uči. Sve navedeno traži visoko promišljanje o odgojno-obrazovnoj djelatnosti unutar tima koji odlikuje visoka razina (jasne) komunikacije, koja dovodi do jasnih ciljeva i misije škole/predškolske ustanove, te, prije svega, kritičko promišljanje o vlastitoj i tuđoj odgojno-obrazovnoj djelatnosti. Autorice rada promiču istraživanja koja se tiču sindroma profesionalnog sagorijevanja kako bi istaknule važnost potrebe širenja novih spoznaja, kao i uvažavanja znanstvenih istraživanja o sindromu profesionalnog sagorijevanja - potencijalnoj prijetnji profesionalnom razvoju učitelja i odgajatelja. 


\title{
THE SCHOOL COUNSELLOR'S ROLE IN PREVENTION OF THE BURN-OUT SYNDROME AMONG TEACHERS AND EDUCATORS
}

\begin{abstract}
The paper analyzes a preventive action of the school counsellor in the form of advisory work focused on teachers and educators. Since the professions of teachers and educators are directed to assistance and support to other people, and since these professions are classified into so-called "helping professions", the professional burn-out at work is an inevitable manifestation of increasing demands placed before them. The research show that the exposure to the increasing demands at all levels of work in "helping professions" leads to extreme levels of negative stress that results in the burn-out syndrome, which has been the subject of the research interest for the past thirty years. Extreme examples of the burn-out syndrome can develop into Karoshi syndrome, which results in death. The paper covers theoretical implications of key concepts, analyzing the phenomenon of the burn-out syndrome in two professions, teachers and educators, and the preventive advisory role of school counsellors who play the contemporary role of a so-called "critical friend"/ "reflexive practitioner" in the "learning community".
\end{abstract}

KEY WORDS: professional stress, working environment, teachers, educators, school counsellor. 


\section{REFERENCE}

Ajduković, M., Ajduković, D. (1996). Pomoć i samopomoć za mentalno zdravlje pomagača. Zagreb: Društvo za psihološku pomoć.

Ajduković, M., Ajduković, D. i Ljubotina, D. (1997). Mental health of helpers: A necessary ingredient of trauma recovery training and assistance in war zones. U: Ajduković, D. (ur.); Trauma Recovery Training: Lessons Learned. Zagreb: Society for Psychological Assistance, 201- 216.

Blaži, D., Heđever M. (2010). Somatske teškoće kao indikatori stresa i teškoće glasa kod odgojiteljica i nastavnika u: Hrvatska revija za rehabilitacijska istraživanja 46 (2); 83-103. Dostupno na http://hrcak.srce.hr/, pristupljeno: 02. lipnja 2015.

Bodlović A., Kucinac S.: Povezivanje teorije i prakse - temelj obrazovanja budućih pedagoga Dostupno na: http://www.pedagogija.hr/ekvilibrij/povezivanje-teorije-i-prakse--temelj-obrazovanja-buducih-pedagoga.html, pristupljeno: 05.06. 2015.

Bognar, B. (2006). Akcijska istraživanja u školi. Odgojne znanosti, 8 (1), $177-190$.

Dostupno na:http://hrcak.srce.hr/index.php?show=clanak\&id_clanak_jezik=414 29, pristupljeno: 02. lipnja 2015.

Brand, S. i Holsboer-Trachsler, E. (2010). Das burnout syndrom - eine übersicht [Prikaz burnout sindroma]. Therapeutische Umschau, 67, 561-565.

Brkić, I., Rijavec, M. (2011). Izvori stresa, suočavanje sa stresom i životno zadovoljstvo učitelja razredne i predmetne nastave u: Napredak: časopis za pedagogijsku teoriju i praksu 152 (2); 211-225. Dostupno na http://hrcak.srce.hr/, pristupljeno: 02. lipnja 2015.

Chan, D. W. (2003). Perceived emotional intelligence and self-effi cacy among school teachers in Hong Kong. Personality and Individual Differences . Dostupno na: www.elsevier.com/locate/tate , pristupljeno: 03. lipnja 2015. 
Costa, L. i Kallick, B. (1993), Through the Lens of a Critical Friend. Educationl Leadership.

Delić, S. (2011). Kritički prijatelj, tko je to? Dostupno na: https://dnevnikuciteljice.wordpress.com/2011/.../kriticki-prijatelj-tkoje-t... Pristupljeno: 05. 06. 2015.

Domović, V., Martinko, J., Jurčec, L. (2010). Čimbenici učiteljskog sagorijevanja na poslu u: Napredak: Časopis za pedagogijsku teoriju $i$ praksu 151 (3-4); 350-369.

Dorman, J. (2003). Testing a model for teacher burnout. Australian Journal of Educational \& Developmental Psychology, 3, 35-47.

Frey Škrinjar, J., Župan Galić, M. (2012). Analiza utjecaja teach programa poučavanja na razlike u strategijama svladavanja profesionalnog sagorijevanja edukacijskih rehabilitatora $\mathrm{U}$ : Hrvatska revija za rehabilitacijska istraživanja 48 (2); 13-22.

Gović, A. (2012). Doživljaj zanesenosti na poslu i osobine ličnosti odgajatelja. (Neobjavljeni diplomski rad). Učiteljski fakultet Sveučilišta u Rijeci, Rijeka.

Jackson, S.E., Schwab-Schuler, R.S. (1986) Toward on understanding of the burnout phenomenon. Journal of Applited Psychology 71, 630-640.

Kadum, V., Vidović, S., Vranković, K. (2007). Gledišta učitelja o svojem statusu, motivaciji i Hrvatskom nacionalnom obrazovnom standardu. Napredak - časopis za pedagogijsku teoriju i praksu, 148 (2); 192209.

Koić, E., Poredoš Lavor, D. (2009). Ekstremni primjer izgaranja na poslu sindrom Karoshi. Polic. sigur., 18(3); 379-385.

Kolić-Vehovec, S. (1998). Edukacijska psihologija. Rijeka, Filozofski falutet.

Lazarus, R.S. (1966). Psychological Stress and the Coping Proces. New York, McGraw-Hill.

Lazarus, R.S. (1975). A cognitively oriented psychologist looks at biofeedback. American Psychologist, 30, 553-561.

Ljubetić, M. (2009). Vrtić po mjeri djeteta. Zagreb: Školske novine. 
Ljubotina, D. i Družić, O. (1996). Sindrom izgaranja na poslu kod pomagača i čimbenici koji utječu na stupanj izgaranja. Ljetopis Studijskog centra socijalnog rada, 3, 51-64.

Mihaliček, S. (2011), Zadovoljstvo i sreća učitelja u: Napredak: časopis za pedagogijsku teoriju i praksu, 152 (3-4); 389 - 401.

Mušanović, M. (2007). Odgojno-obrazovne filozofije učitelja i akcijsko istraživanje, dostupno na: www.ffri.hr/pedagogija/OPATIJA\% 20RADOVI.doc pristupljeno 02. lipnja 2015.

Radeka, I., Sorić, I. (2006). Zadovoljstvo poslom i profesionalni status nastavnika. U Napredak: časopis za pedagogijsku teoriju i praksu, 147(2), 161-177.

Resman, M. (2000). Savjetodavni rad u vrtiću i školi. Zagreb: HPKZ.

Slišković, A., Maslić Seršić D., Burić I. (2012). Izvori stresa u radu nastavnika u visokom obrazovanju. U: Psihologijske teme 21 (1); 83103. Dostupno na http://hrcak.srce.hr/, pristupljeno: 02. lipnja 2015.

Tatalović Vorkapić, S., Lončarić, D. (2013). Posreduje li profesionalno sagorijevanje učinke osobina ličnosti na zadovoljstvo životom odgojitelja predškolske djece? U: Psihologijske teme 22 (2013), 3, 431-445.

Tatalović Vorkapić, S. i Mustapić, J. (2012), Internal and external factors in professional burnout of substance abuse counsellors in Croatia. Annali dell' Istituto Superiore di Sanita, 48(2), 187-195.

Šagud, M. (2006), Odgajatelj kao refleksivni praktičar. Petrinja: Visoka učiteljska škola.

Škes Marija (2010), Radimo zdravo - Kako spriječiti sagorijevanje na radnom mjestu, Zavod za javno zdravstvo "Dr. Andrija Štampar", Zagreb.

Škrinjar, J. (1996), Odnos zanimanja i strategija suočavanja i svladavanja Burnout sindroma. Hrvatska revija za rehabilitacijska istraživanja, 32 (1) 25-36.

Vidić, T. (2009), Zadovoljstvo poslom učitelja u osnovnoj školi. Napredakčasopis za pedagogijsku teoriju i praksu, 150 (1), 7-20.

Živčić-Bećirević, I. i Smojver-Ažić, S. (2005), Izvori stresa na poslu odgojitelja u dječjim vrtićima. Psihologijske teme, 14(2), 3-13. 
Žužul, M. i Raboteg - Šarić, Z. (1992). Ratni stres u djece, suzbijanje, posljedice i liječenje. Zagreb: Ministarstvo obrane RH. Uprava za informativno-psihološku djelatnost. 